Article

\title{
Embodied Energy and Environmental Impact of Large-Power Stand-Alone Photovoltaic Irrigation Systems
}

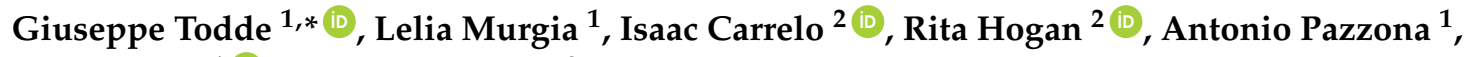 \\ Luigi Ledda ${ }^{1}$ (1) and Luis Narvarte ${ }^{2}$ \\ 1 Department of Agricultural Science, University of Sassari, Viale Italia 39, 07100 Sassari, Italy; \\ dit_mecc@uniss.it (L.M.); pazzona@uniss.it (A.P.); lledda@uniss.it (L.L.) \\ 2 PV Systems Research Group, Instituto de Energía Solar, Universidad Politécnica de Madrid, \\ 28040 Madrid, Spain; isaac.barata@ies-def.upm.es (I.C.); rita.hogan@ies.upm.es (R.H.); \\ navarte@ies-def.upm.es (L.N.) \\ * Corresponding: gtodde@uniss.it; Fax: +39-079-229-285
}

Received: 23 July 2018; Accepted: 10 August 2018; Published: 14 August 2018

\begin{abstract}
A life cycle assessment (LCA) methodology was used to evaluate the cumulative energy demand and the related environmental impact of three large-power stand-alone photovoltaic (PV) irrigation systems ranging from $40 \mathrm{kWp}$ to $360 \mathrm{kWp}$. The novelty of this analysis is the large power of these systems as the literature up to now is restricted to modeled PV pumping systems scenarios or small power plants, where the size can be a critical factor for energy and environmental issues. The analysis shows that the yearly embodied energy per unit of PV power ranged from $1306 \mathrm{MJ} / \mathrm{kWp}$ to $1199 \mathrm{MJ} / \mathrm{kWp}$ depending of the PV generator size. Similarly, the related yearly carbon dioxide impacts ranged from 72.6 to $79.8 \mathrm{~kg} \mathrm{CO}_{2} \mathrm{e} / \mathrm{kWp}$. The production of PV modules accounted for the main portion (about $80 \%$ ) of the primary energy embodied into the PV irrigation system (PVIS). The outcomes of the study also show an inverse trend of the energy and carbon payback times respect to the PV power size: In fact, energy payback time increased from 1.94, to 5.25 years and carbon payback time ranged from 4.62 to 9.38 years. Also the energy return on investment depends on the PV generator dimension, ranging from 12.9 to 4.8. The environmental impact of the stand-alone PV systems was also expressed in reference to the potential amount of electricity generated during the whole PV life. As expected, the largest PVIS performs the best result, obtaining an emission rate of $45.9 \mathrm{~g} \mathrm{CO}_{2} \mathrm{e}$ per $\mathrm{kWh}$, while the smallest one achieves $124.1 \mathrm{~g} \mathrm{CO}_{2}$ e per $\mathrm{kWh}$. Finally, the energy and environmental indicators obtained in this study are strongly related to the irrigation needs, which in turn are influenced by other factors as the type of cultivated crops, the weather conditions and the water availability.
\end{abstract}

Keywords: life cycle assessment; solar energy; PV water pumping; GHG agriculture; diesel fuel; electricity

\section{Introduction}

In the last decades the need to find alternative sources of energy other than fossil fuels has increasingly become one of the most important option to deal with the climate change. The production of renewable electricity by means of photovoltaic (PV) systems is rapidly expanding $[1,2]$ thanks to their capability to decrease the energy consumption from conventional sources and to reduce the environmental load [3]. Moreover, the financial incentives and the price reduction of photovoltaic modules are promoting PV application worldwide [4-8]. In 2016 the total installed PV capacity globally amounted to $303 \mathrm{GWp}$, where Italy and Spain held 19.3 and $5.4 \mathrm{GWp}$, respectively [9]. The production of photovoltaic electricity is considered clean energy. In fact, during the operational phase of the PV 
power plant, direct greenhouse gas emissions into the atmosphere are nil as the only energy used comes from the solar radiation. Nevertheless, analyzing the whole life cycle, a photovoltaic power plant requires a certain amount of primary energy, mainly during the manufacturing and installation phases of the PV components. This embodied energy generates also greenhouse gas (GHG) emissions that can be referred to the whole energy produced during the entire life of the PV system $[10,11]$.

The Life Cycle Assessment (LCA) methodology is considered one of the most complete tools to quantify the environmental impacts of a PV system throughout its whole lifetime, starting from the extraction of raw materials, the manufacturing processes, the transport, the operation during its useful life, until its final recycling or management as waste [12-14].

A large number of LCA studies have been carried out on solar energy production technologies [15-20] and, specifically, on stand-alone PV plants [21-26]. PV systems have been also integrated in several agricultural contexts and, in particular, to supply energy for water pumping for irrigation purposes [27-30]. In fact, irrigation is usually associated with high fossil energy requirements and thus environmental emissions [31-34].

LCA studies have already been done on PV pumping systems in order to estimate the mitigation potential of replacing grid-powered irrigation in South African maize production [35], to assess environmental benefits of water pumping and desalination process powered by PV and Wind systems [36] and to evaluate the carbon emission performance of a $3.4 \mathrm{kWp}$ PV water pumping system in China [37]. Although, these systems are restricted into a modeled PV pumping scenario or systems of small power size.

It is very likely that environmental parameters like the embodied energy, the energy and carbon payback periods (EPBT and CPBT) and the energy return on investment (EROI) are highly dependent on the size of the PV irrigation system (PVIS). The novelty of this paper is that these environmental parameters are analyzed for large-power PVIS, taking advantage of the monitoring of the performance during two years of three real-scale demonstrators installed in the framework of an European project called Maslowaten [38] in Villena (Spain, $360 \mathrm{kWp}$ ), Alaejos (Spain, $160 \mathrm{kWp}$ ) and Uri (Italy, $40 \mathrm{kWp}$ ). To the best knowledge of the authors, this is the first time that a LCA analysis is done with large-power PVIS. Moreover, this range of powers (from 40 to $360 \mathrm{kWp}$ ) has allowed analyzing the relationship between the PV generator size and the environmental impact indexes, showing that the bigger the PVIS size, the lower the environmental impact. This study analyzes and evaluates the dependency of the cumulative primary energy demand (CED) and the related emissions, EPBT, CPBT and EROI on the size of the PVIS and on other factors like the water needs of the cultivated crops and the water availability.

\section{Materials and Methods}

\subsection{Scope and Data Source}

A LCA approach [39-42] was applied to evaluate the cumulative energy demand and the carbon footprint of large-power stand-alone PVIS, equipped with solar trackers located in Spain and Italy with different agricultural production systems. Table 1 summarizes the main characteristics of these PVIS.

The largest PVIS, with a nominal power of $360 \mathrm{kWp}$ and assembled with 1440 panels was installed in Villena (Spain) and equipped with a three phase at $400 \mathrm{~V}$ inverter of $355 \mathrm{~kW}$. The total area occupied by the PV generator is about 1 hectare. The PV system is arranged into 18 North-South (N-S) horizontal axis having 80 panels each and connected to a sun tracker system. The sun tracker system is composed by two multi rows systems (eight axes each) and two single rows managing one axis each (Figure 1). 


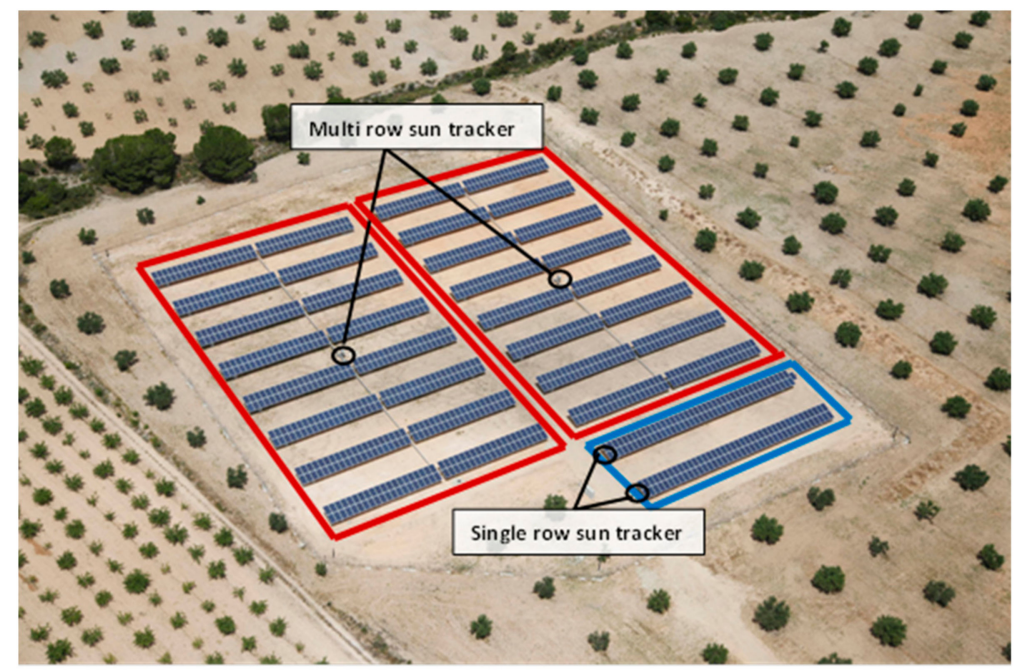

Figure 1. Photovoltaic (PV) irrigation system installed in Villena (Spain) and sun tracking system disposition.

Table 1. Characteristics of the Photovoltaic (PV) irrigation systems involved in the study.

\begin{tabular}{|c|c|c|c|}
\hline Demonstrators & $\begin{array}{l}\text { Spain } \\
\text { (Villena) }\end{array}$ & $\begin{array}{c}\text { Spain } \\
\text { (Alaejos) }\end{array}$ & $\begin{array}{l}\text { Italy } \\
\text { (Uri) }\end{array}$ \\
\hline Longitude & $0^{\circ} 50^{\prime} 32^{\prime \prime} \mathrm{W}$ & $5^{\circ} 16^{\prime} 36^{\prime \prime} \mathrm{W}$ & $40.62^{\circ} \mathrm{N}$ \\
\hline Latitude & $38^{\circ} 14^{\prime} 19^{\prime \prime} \mathrm{N}$ & $41^{\circ} 16^{\prime} 21^{\prime \prime} \mathrm{N}$ & $8.47^{\circ} \mathrm{E}$ \\
\hline Altitude (m) & 593 & 794 & 128 \\
\hline Crop systems & Various & Rapeseed-poppy-potato-sugar beet & Artichoke-Wheat \\
\hline Water needs $\left(\mathrm{m}^{3} / \mathrm{y}\right)$ & 650,000 & 360,000 & 60,000 \\
\hline Water source & Well & Well & 2 Wells \\
\hline Well depth (m) & 290 & 140 & $68 / 98$ \\
\hline Well flow $(1 / \mathrm{s})$ & 63 & 45 & $3+5 / 10$ \\
\hline Pumps (n) & 1 & 2 & 2 \\
\hline Pumps power $(\mathrm{kW})$ & 250 & $92+30$ & $3+18.5$ \\
\hline Photovoltaic power $(\mathrm{kWp})$ & 360 & 160 & 40 \\
\hline Inverters $(\mathrm{n} \times$ power $)$ & $1 \times 355 \mathrm{~kW}$ & $\begin{array}{c}1 \times 110 \mathrm{~kW} \\
1 \times 37 \mathrm{~kW}\end{array}$ & $\begin{array}{l}1 \times 22 \mathrm{~kW} \\
1 \times 5.5 \mathrm{~kW} \\
1 \times 11 \mathrm{~kW}\end{array}$ \\
\hline $\begin{array}{l}\text { Photovoltaic Tracker } \\
\text { Systems }(\mathrm{n} \times \text { type })\end{array}$ & $\begin{array}{l}2 \times \mathrm{H} 1250 \text { multi-rows }(8 \text { axis }) \\
2 \times \mathrm{H} 160 \text { single-row }(1 \text { axe })\end{array}$ & $\begin{array}{c}1 \times \mathrm{H} 1250 \text { multi-rows }(6 \text { axis }) \\
2 \times \mathrm{H} 160 \text { single-row }(1 \text { axe })\end{array}$ & $2 \times$ H160 single-row (1 axis) \\
\hline Area occupied $\left(\mathrm{m}^{2}\right)$ & 7206 & 3203 & 801 \\
\hline
\end{tabular}

The irrigation community of Alto Vinalopó hosting the demonstrator is devoted to supply water to other smaller irrigation communities with different crop productions. The PVIS is equipped with a $250 \mathrm{~kW}$ submersible pump which moves the water from a depth of $288 \mathrm{~m}$ to a reservoir with a capacity of $173,000 \mathrm{~m}^{3}$. The yearly water needs are around $650,000 \mathrm{~m}^{3}$.

The second PVIS was mounted in Alaejos (Spain). The PV generator holds $160 \mathrm{kWp}$ arranged into $8 \mathrm{~N}-\mathrm{S}$ horizontal axis having 80 panels each and equipped with sun trackers (Figure 2). The system mounts two inverters ( 37 and $110 \mathrm{~kW}$ ) in order to generate electricity to supply two pumps of 92 and $30 \mathrm{~kW}$ power. The first one to pump from a $150 \mathrm{~m}$ deep well to an intermediate $1000 \mathrm{~m}^{3}$ water tank, and the second to pump from the tank to the irrigation network. The annual water needs are about $360,000 \mathrm{~m}^{3}$. The Alaejos PVIS had previously a fuel generator to supply electricity. It has been kept and it can be used when the PV system does not provide enough energy to keep irrigation working during low availability of radiation or at nights. The PVIS supply electricity to the Cooperative "La Estrella de San Juan", with a total area of 80 hectares where the most representative crops are potato, sugar beet, poppy and rapeseed. 


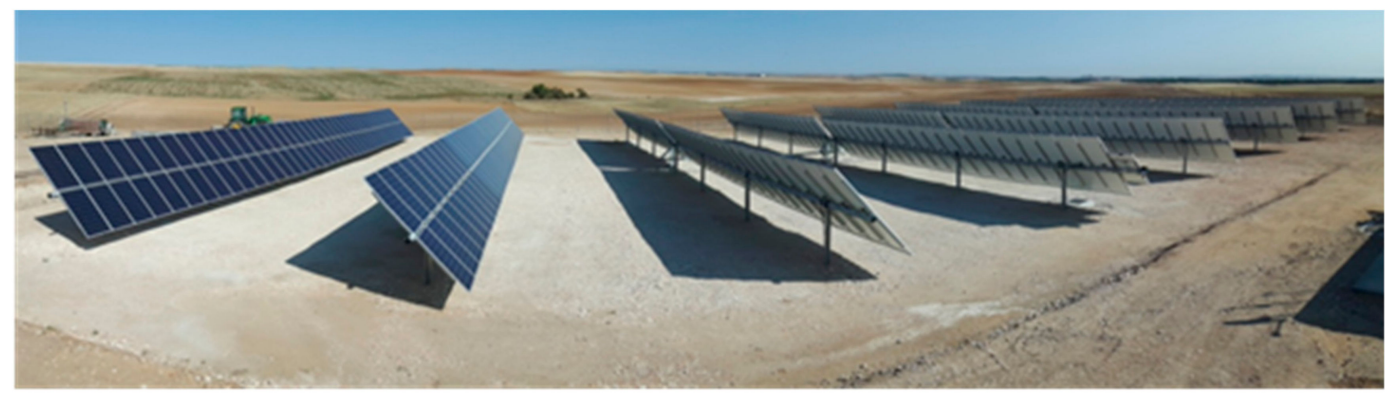

Figure 2. Stand-alone PV irrigation system (PVIS) installed in Alaejos (Spain).

The smallest PV generator was installed in Uri (Sassari, Italy), in the "Sarciofo" Farm, devoted to the cultivation of artichoke and wheat. The farm holds 10 hectares of cultivated land equipped with a sprinkler irrigation system. The $40 \mathrm{kWp} \mathrm{PV} \mathrm{generator} \mathrm{is} \mathrm{ground} \mathrm{mounted} \mathrm{on} \mathrm{two} \mathrm{N-S} \mathrm{horizontal}$ axis sun trackers (Figure 3). The total area occupied by the PV generator is about $800 \mathrm{~m}^{2}$. The water needs of the farm are about $60,000 \mathrm{~m}^{3}$ per year, provided from two wells (depth around 70 and $90 \mathrm{~m}$ ), equipped with two pumps of 3 and $18.5 \mathrm{~kW}$, respectively, that elevate water to the water tank. Irrigation is supplied by a $7.5 \mathrm{~kW}$ centrifugal surface horizontal axe pump. The stand-alone PVIS allows irrigating crops mainly to the use of PV electricity and turn on to the previous grid system when the renewable energy is not enough.

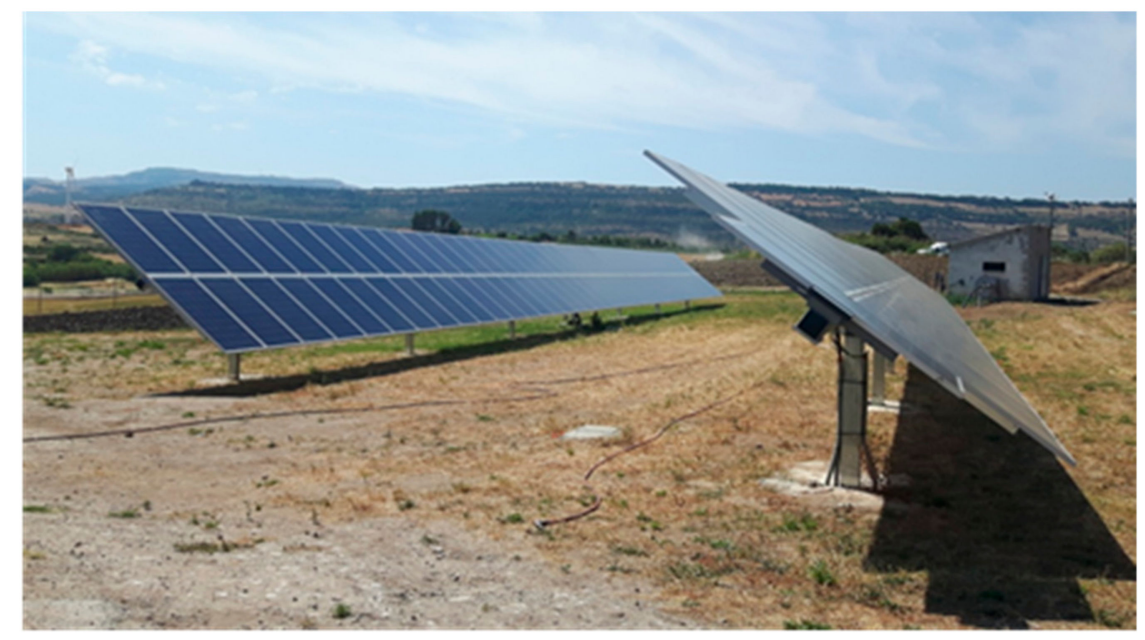

Figure 3. Stand-alone PVIS installed in Uri (Sassari, Italy).

As it can be observed, these three large-power PVIS cover a wide range of powers (from $40 \mathrm{kWp}$ to $360 \mathrm{kWp}$ ) and, therefore, they allow analyzing the dependency of the LCA results on the PVIS size.

\subsection{System Boundaries and Functional Unit}

The system boundaries (Figure 4) were set from cradle-to-grave, which involves the assessment of the environmental impact of each phase of manufacturing (from raw material extraction to product assembly), distribution (from production site to end user), use and end of life treatment (recycling). The end of life treatment of PV components represents a debated issue in several LCA studies [43-46]. The long life span of PV systems and the current low amount of PV waste treated in the recycling facilities, limit the research on end of life issues so far [47]. However, the EU directive of waste of electric and electronic equipment included the PV component in the list of materials which require a proper end of life treatment since 2012 [48]. Moreover, the end of life treatment is becoming increasingly important since the expected increase of PV waste in the next decades [44,49]. For these reasons, the system boundaries 
of this study were extended until the recycling treatment, using as primary energy and emission factors the values $2780 \mathrm{MJ}$ and $370 \mathrm{~kg} \mathrm{CO}_{2} \mathrm{e}$ per tonne of silicon photovoltaic waste, respectively. These factors include dismantling of the PV plant, transport and recycling treatment [47].

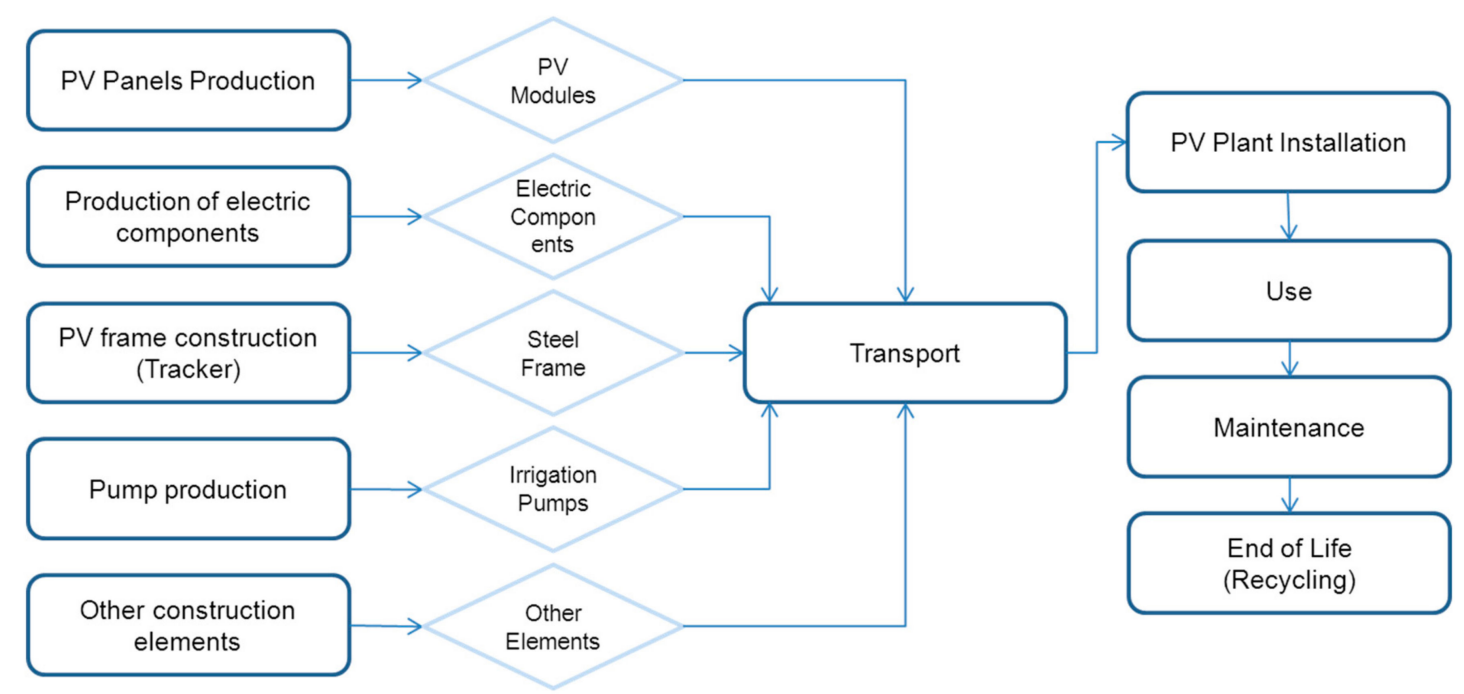

Figure 4. Life cycle of the stand-alone PVIS.

The functional units of the study were set to $1 \mathrm{kWp}$ of PV system installed and $1 \mathrm{kWh}$ of PV electricity supplied to the irrigation systems.

\subsection{Life Cycle Inventory}

The life cycle inventory comprises a detailed data set of inputs (PVIS components) and outputs (electricity generated) related to the studied system. In this assessment the PVIS have been split into the following components, including:

PV panels of $250 \mathrm{Wp}$;

Wiring;

Inverters;

Other electric components;

Pumps;

Galvanized steel PV plant frame;

N-S solar trackers;

Foundation (reinforced concrete);

Civil works (digging, excavation, etc.);

Fence.

The data collected were obtained from the inventory list of Maslowaten project and, when available, from farmer interviews. Moreover, the transportation of the components were taken into account, assessing the distance from the manufacturing company to each one of the PVIS sites. Road transportation on lorries (16-32 tonnes Euro 5) was considered for all the demonstrators, while maritime transport via ship was calculated only for the components sent to Uri (Sardinia, Italy).

The maintenance of the PVIS was included in the LCA analysis, in particular the weed control and the PV panels cleaning. The electricity consumption of the solar tracker system during the PVIS operation was also accounted in the analysis.

The electricity produced by the PV generator has been recorded for the 2016 and 2017 year to allow quantifying the energy and the environmental benefits obtained by the use of these systems. While 2016 
was a standard year from the climatological point of view, 2017 was characterized by a hard drought and lack of water.

\subsection{Impact Assessment}

The methodology used to quantify the energy and the environmental impact of the PVIS has considered two impact categories: the CED and the climate change. Moreover, the EROI, the energy payback time and the $\mathrm{CO}_{2}$ payback time were assessed.

In the one hand, CED is widely used to define the primary energy required to obtain a product or a service throughout its entire life cycle. Results of this analysis are reported in MJ of energy consumed per unit of PV power or PV energy produced by the PVIS.

The potential climate change impact of each GHG emitted by the product system has been assessed multiplying the mass of a given GHG, using the 100-year time horizon, by its global warming potential (GWP) defined by the IPCC [42,50]. In fact, the GWP represents the contribution of each released GHG to the greenhouse effect and it is expressed in terms of $\mathrm{kg}$ carbon dioxide equivalent $\left(\mathrm{CO}_{2} \mathrm{e}\right)$.

The energy equivalents and carbon dioxide emissions derived from the life cycle of each component installed was calculated multiplying its coefficient to the specific emission factors listed in Table 2.

Table 2. Main energy equivalents and emission factors used for the Energy Life Cycle Assessment of stand-alone PVIS.

\begin{tabular}{|c|c|c|c|c|c|c|}
\hline \multirow{2}{*}{$\begin{array}{c}\text { Item } \\
\text { PV panels }\end{array}$} & \multicolumn{2}{|c|}{ ENERGY } & \multicolumn{2}{|c|}{ EMISSION } & \multirow{2}{*}{$\begin{array}{c}\text { References } \\
{[51]}\end{array}$} & \multirow{2}{*}{$\frac{\text { LifeTime }(\mathbf{y})}{25}$} \\
\hline & 3640 & $\mathrm{MJ} / \mathrm{m}^{2}$ & 213 & $\mathrm{kgCO} \mathrm{CO}_{2} \mathrm{e} / \mathrm{m}^{2}$ & & \\
\hline PV recycling & 2780 & $\mathrm{MJ} / \mathrm{t}$ & 370 & $\mathrm{~kg} \mathrm{CO}_{2} \mathrm{e} / \mathrm{t}$ & [47] & 25 \\
\hline Inverter small & 1085 & $\mathrm{MJ} / \mathrm{kW}$ & 71 & $\mathrm{~kg} \mathrm{CO}_{2} \mathrm{e} / \mathrm{kW}$ & [51] & 15 \\
\hline Inverter large & 492 & $\mathrm{MJ} / \mathrm{kW}$ & 29.6 & $\mathrm{kgCO}_{2} \mathrm{e} / \mathrm{kW}$ & [51] & 15 \\
\hline Other components & 992 & $\mathrm{MJ} / \mathrm{kg}$ & 65 & $\mathrm{~kg} \mathrm{CO}_{2} \mathrm{e} / \mathrm{kg}$ & [51] & 20 \\
\hline Wiring & 183 & $\mathrm{MJ} / \mathrm{m}$ & 4.473 & $\mathrm{~kg} \mathrm{CO}_{2} \mathrm{e} / \mathrm{m}$ & [51] & 20 \\
\hline Pumps & 64.8 & $\mathrm{MJ} / \mathrm{kg}$ & 3.54 & $\mathrm{~kg} \mathrm{CO} \mathrm{CO}_{2} \mathrm{e} / \mathrm{kg}$ & $\begin{array}{l}{[52]} \\
{[53]}\end{array}$ & 20 \\
\hline Steel & 24.2 & $\mathrm{MJ} / \mathrm{kg}$ & 1.76 & $\mathrm{kgCO}_{2} \mathrm{e} / \mathrm{kg}$ & Our Calculation & 20 \\
\hline Reinforced concrete & 1.56 & $\mathrm{MJ} / \mathrm{kg}$ & 0.18 & $\mathrm{kgCO}_{2} \mathrm{e} / \mathrm{kg}$ & Our Calculation & 20 \\
\hline Excavation digger & 8.41 & $\mathrm{MJ} / \mathrm{m}^{3}$ & 0.552 & $\mathrm{kgCO} \mathrm{CO}_{2} \mathrm{e} / \mathrm{m}^{3}$ & [51] & 25 \\
\hline Road Transport & 2.76 & $\mathrm{MJ} / \mathrm{tkm}$ & 0.17 & $\mathrm{kgCO}_{2} \mathrm{e} / \mathrm{tkm}$ & [51] & 20 \\
\hline Transport sea ship & 0.179 & $\mathrm{MJ} / \mathrm{tkm}$ & 0.0116 & $\mathrm{kgCO} \mathrm{CO}_{2} \mathrm{e} / \mathrm{km}$ & [51] & 20 \\
\hline Electricity (Italy) & 9.67 & $\mathrm{MJ} / \mathrm{kWh}$ & 0.3306 & $\mathrm{kgCO}_{2} \mathrm{e} / \mathrm{kWh}$ & {$[54,55]$} & - \\
\hline Electricity (Spain) & 9.76 & $\mathrm{MJ} / \mathrm{kWh}$ & 0.2483 & $\mathrm{~kg} \mathrm{CO} \mathrm{CO}_{2} \mathrm{e} / \mathrm{kWh}$ & {$[54,56]$} & - \\
\hline
\end{tabular}

In the other hand, the most adopted procedures to evaluate energy and environmental benefits through the use of renewable technologies are represented by the energy and $\mathrm{CO}_{2}$ payback times [57-61].

These methods consider the primary energy consumed (MJ) and the GHG generated (kg) throughout the entire life time cycle (from cradle to grave) of the studied product, divided by the MJ of primary energy and $\mathrm{kg}$ of $\mathrm{CO}_{2} \mathrm{e}$ produced or saved during the whole life span.

The Energy Payback Time (EPBT), which refers to the time necessary for the PVIS to save the same amount of primary energy consumed during its life cycle, was calculated applying the following formula:

$$
\text { EPBT }(\text { years })=\frac{\text { MJ of primary energy spent from cradle to grave }}{\text { MJ of annual primary energy saved }}
$$

The Carbon dioxide Payback Time (CPBT), that express the time necessary for the PVIS to avoid the same amount of $\mathrm{CO}_{2} \mathrm{e}$ emitted during its life cycle, was evaluated by the following formula:

$$
\mathrm{CPBT}(\text { years })=\frac{\mathrm{kg} \mathrm{CO}_{2} \mathrm{e} \text { emitted from cradle to grave }}{\mathrm{kg} \mathrm{CO}_{2} \mathrm{e} \text { avoided per year }}
$$


The long-term viability of an energy generating systems can be evaluated as the EROI, that is a dimensionless ratio of the amount of energy obtained from a generation system, divided by the amount of energy invested in that system, along its entire life-cycle [62].

$$
\mathrm{EROI}=\frac{\text { MJ of energy produced from PV systems (25 years) }}{\mathrm{MJ} \text { of primary energy spent to create PV systems (cradle to grave) }}
$$

When assessing the energy and environmental impacts of the PV systems, the specific factors related to each country mix electricity generation were considered. The primary energy factors ranged from 9.67 MJ per kWh produced in Italy to $9.76 \mathrm{MJ}$ per $\mathrm{kWh}$ of electricity produced in Spain [54]. In regard to $\mathrm{CO}_{2} \mathrm{e}$ emission factors, the lowest value, $0.2483 \mathrm{~kg} \mathrm{CO}_{2} \mathrm{e}$ per $\mathrm{kWh}$ was found in Spain [56], while the electricity produced in Italy accounted for $0.3306 \mathrm{~kg} \mathrm{CO}_{2} \mathrm{e}$ per $\mathrm{kWh}$ [55].

To evaluate the MJ of annual primary energy produced/saved and the avoided emissions of $\mathrm{CO}_{2} \mathrm{e}$, a realistic scenario per each project site was developed. The realistic scenario takes into account one critical year like 2017 (low use of the systems due to unfavorable environmental conditions, for example lack of water to irrigate due to droughts) every 5 favorable years like 2016 (positive environmental conditions). This scenario was used to assess the EPBT, CPBT, EROI and the related emissions of

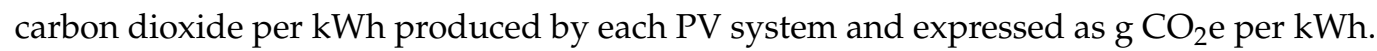

In addition to the life cycle assessment study, the consumption of fossil fuels were taken into account for the PVIS with conventional-energy back-up. The analyses of total electricity and diesel fuel requirements, before and after the installation of the PVIS were performed. Moreover, the related emissions of carbon dioxide were evaluated in order to quantify the environmental benefit obtained through the use of PVIS.

\section{Results and Discussions}

\subsection{CED and GHG Emissions}

In order to quantify the cumulative energy demand and the environmental impact of the large-power stand-alone PVIS depending on their size, the contributions of each component of the installation were added together obtaining the total embodied energy, expressed in MJ, and the related total carbon dioxide emitted (tonne of $\mathrm{CO}_{2} \mathrm{e}$ ). Total primary energy of the PVIS accounted to $1306 \mathrm{GJ}$ for the Italian installation, while 5186 and 10,788 GJ for the ones installed in Alaejos and Villena (Spain), respectively. The associated carbon dioxide emitted by the PVIS during its life time vary from 80 to 654 tons of $\mathrm{CO}_{2} \mathrm{e}$ (Figure 5). The high variations among the three PVIS derive from the different size of each one. To express the energy and environmental burdens as indexes, the total values have been divided by each individual life span (reported in Table 2) and then by the nominal power of the PVIS. The results show the largest yearly incidence of $1306 \mathrm{MJ} / \mathrm{kWp}$ for the Italian PVIS (the smallest one), while the lowest values were found in Villena with $1199 \mathrm{MJ} / \mathrm{kWp}$ (the largest one). Similarly, the annual values of carbon dioxide impacts show the same dependency with PVIS size, with indexes ranging from 72.6 to $79.8 \mathrm{~kg} \mathrm{CO} 2 \mathrm{e} / \mathrm{kWp}$ (Table 3). 


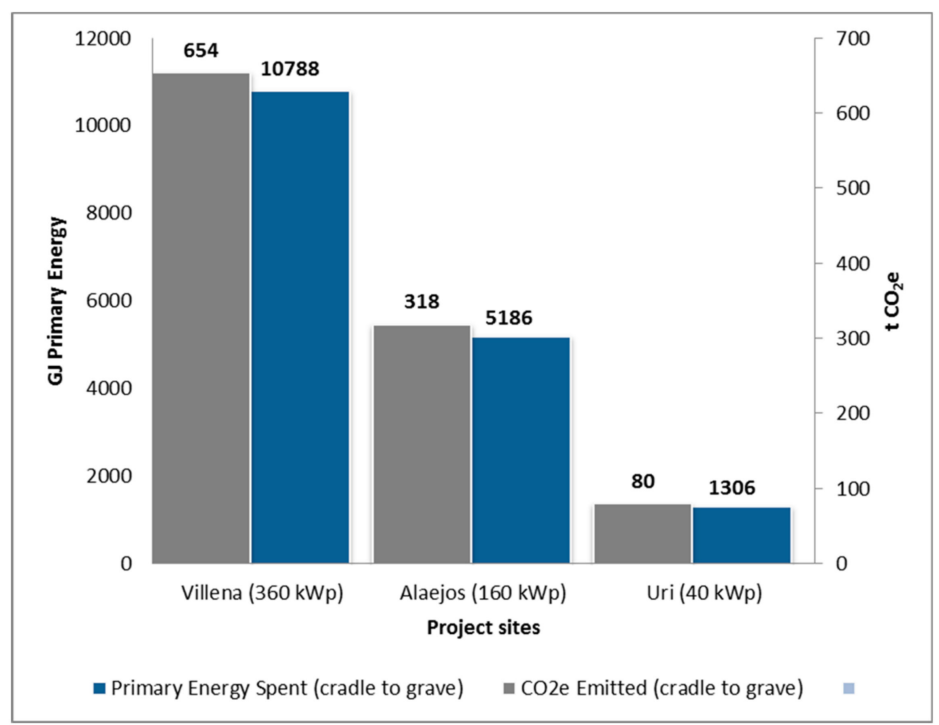

Figure 5. Primary energy spent and carbon dioxide emitted, from cradle to grave, from the 3 project sites.

Table 3. Energy and Carbon dioxide results expressed per year in references to the nominal power $(\mathrm{kWp})$ and PV surface $\left(\mathrm{m}^{2}\right)$ of each plant.

\begin{tabular}{cccc}
\hline Title & Villena (360 kWp) & Alaejos (160 kWp) & Uri (40 kWp) \\
\hline $\begin{array}{c}\text { Primary Energy } \\
\text { (MJ / kWp per year) }\end{array}$ & 1199 & 1295 & 1306 \\
$\begin{array}{c}\text { Carbon dioxide } \\
\text { (kg CO } 2 \text { e/kWp per year })\end{array}$ & 72.6 & 79.4 & 79.8 \\
$\begin{array}{c}\text { Energy production } \\
(\mathrm{kWh} / \mathrm{kWp} \text { per year })\end{array}$ & 1582 & 1213 & 644 \\
\hline
\end{tabular}

Additionally, by splitting the energy results we are able to find the contribution of each PVIS component to CED. As depicted in Figure 6, the production of PV modules represents the main portion (about $80 \%$ ) of the primary energy embodied into the PVIS, followed by other components $(5.8 \%)$, plant steel frame $(5.4 \%)$, civil works and inverters (3\% each). The "other components" group refers to solar tracking systems, auxiliary PV panels (to supply auxiliary services), wiring and conduits.

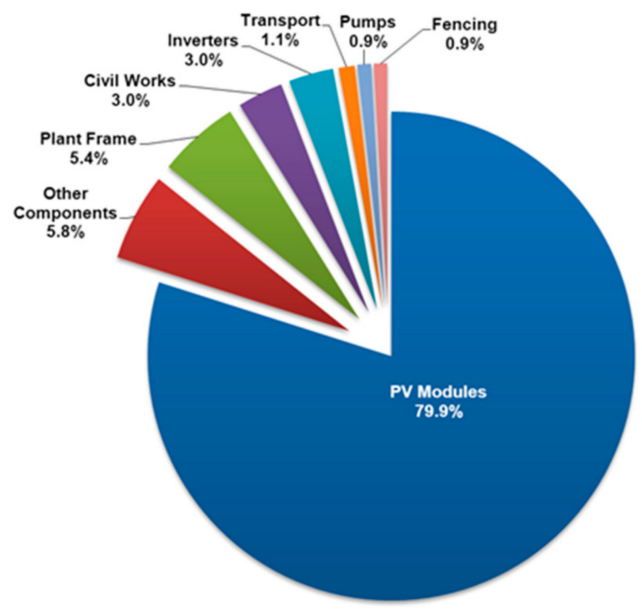

Figure 6. Distribution of the primary energy embodied in each component (average among the 3 stand alone PVIS). 
Correspondingly, the PV panels and the plant steel frame showed the highest quota of carbon dioxide emissions, while maintenance and pumps showed negligible values (Figure 7).

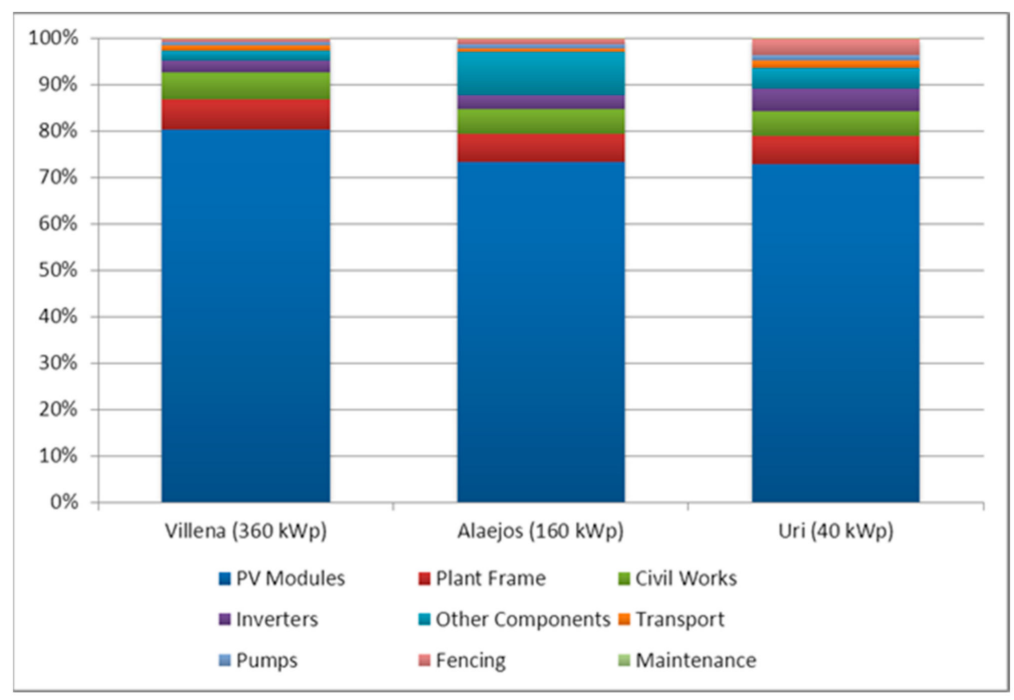

Figure 7. Distribution of the carbon dioxide emitted by each component (from cradle to grave) per PVIS.

The total $\mathrm{CO}_{2}$ emitted from each component was divided by the related working life and the nominal power of the PV installation (Table 4). The environmental load of the PVIS components differ mainly for the inverters from 2 to $3.9 \mathrm{~kg} \mathrm{CO} 2 \mathrm{e} / \mathrm{kWp}$ per year and the other components from 1.4 to $7.3 \mathrm{~kg}$ $\mathrm{CO}_{2} \mathrm{e} / \mathrm{kWp}$ per year. As expected, the PVIS installed in Sardinia showed a significant increment in the transport phase, about $1.4 \mathrm{~kg} \mathrm{CO} 2 \mathrm{e} / \mathrm{kWp}$ per year. It can be observed that this impact also depends on the size of the PVIS.

Table 4. Carbon dioxide burdens $\left(\mathrm{kg} \mathrm{CO}_{2} \mathrm{e} / \mathrm{kWp}\right)$ expressed per year in reference to the nominal power of each PVIS.

\begin{tabular}{cccc}
\hline Equipment & Villena (360 $\mathbf{k W})$ & Alaejos (160 $\mathbf{k W p})$ & Uri $\mathbf{( 4 0} \mathbf{k W} \mathbf{p})$ \\
\hline PV Modules & 58.1 & 58.1 & 58.1 \\
Plant Frame & 4.9 & 4.9 & 4.8 \\
Civil Works & 4.1 & 4.2 & 4.1 \\
Inverters & 2.0 & 2.4 & 3.9 \\
Other Components & 1.4 & 7.3 & 3.5 \\
Transport & 0.8 & 0.6 & 1.4 \\
Pumps & 0.6 & 0.7 & 0.9 \\
Fence & 0.5 & 1.0 & 2.7 \\
Maintenance & 0.2 & 0.3 & 0.3 \\
\hline
\end{tabular}

\subsection{EPBT, $C P B T$ and EROI}

Resulting EPBT and CPBT values are shown in Figure 8. EPBT and CPBT depend on many factors that influence the energy generation capacity, such as PV cells and PVIS efficiencies, local irradiation and mean ambient temperature of the location. The results obtained show an inverse trend of the EPBT and CPBT with respect to the PVIS size. In fact, EPBT increased from 1.94 to 2.74 and 5.25 years, passing from the largest to the smallest PVIS, likewise the CPBT which ranged from 4.62 to 9.38 years. This means that a large quota (respectively $92 \%, 89 \%$ and $79 \%$ ) of the energy generated by these PVIS during their lifetime (25 years) will not produce any air pollution and depletion of resources. These results clearly highlighted the benefit obtained through large PVIS, in fact the economies of scale play a significant role 
for a faster repay of the energy investments. However, even the higher values obtained in this study could be considered more than acceptable since the long life span of the PV systems.

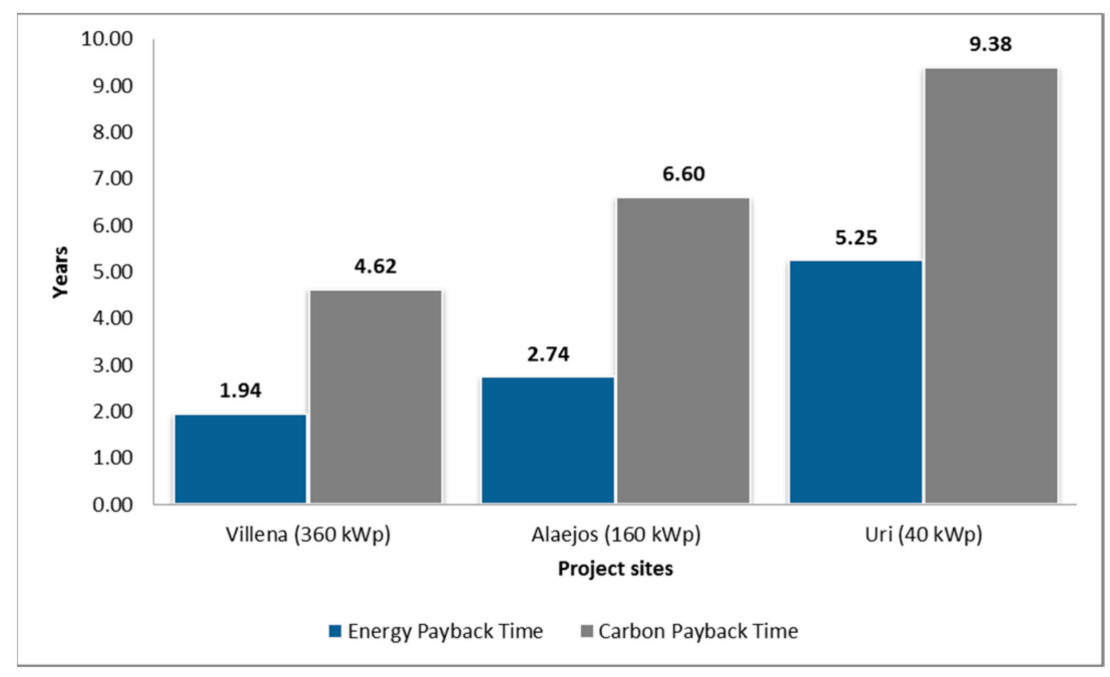

Figure 8. Energy and carbon payback times (from cradle to grave) per PVIS.

Similarly, other studies carried out on life cycle assessment of PV plants underlined how the power size of the installations may play a significant role when assessing energy payback time. In fact, small PV plants reported an EPBT of 9.08 years for a $4.2 \mathrm{kWp}$ mono-crystalline silicon modules implemented in a stand-alone PV system installed in Spain [26] and 18.9 years for a ground mounted $2.32 \mathrm{kWp}$ stand-alone PV system installed in India [23], while Yu and Halog [18] found an EPBT of 2.33 years for a large multi-Si PV with 1.2 MW flat-roof mounted in Australia.

The results related to the EROI showed the same dependency on PVIS size: greater values for the Villena and Alaejos demonstrators, 12.9 and 9.1 respectively, while the PVIS installed in Uri performed an EROI of 4.8. As reported by Hall et al. [63] the EROI should be at least 3:1 to be considered a viable energy source for the society. Moreover, Bahandari et al. [62] reported a harmonized EROI of 10 studies on multi-Si PV systems where the mean value accounted to 11.6 and a standard deviation of 5.2.

The carbon impact of the stand-alone PVIS has also been expressed in reference to the potential amount of electricity generated during the entire PVIS lifetime. As expected, the largest one (Villena) performed the best result, obtaining an emission factor of $45.9 \mathrm{~g} \mathrm{CO}_{2} \mathrm{e}$ per $\mathrm{kWh}$, while Alaejos and Uri systems achieved 65.6 and $124.1 \mathrm{~g} \mathrm{CO}_{2}$ e per $\mathrm{kWh}$, respectively. The high $\mathrm{CO}_{2}$ emission rate obtained in the PVIS in Uri is also due to the fact that the PV energy production is directly connected to the use of the irrigation systems which may depend on external factors like the water needs of the crop or the lack of water in the source. This was the case of the year of analysis (2017), with an under-use of the PVIS due to a hard drought which led to lack of water in the wells. Although the PVIS has the potential of irrigating $72,000 \mathrm{~m}^{3}$ /year, the farmer was only been able to use $20,838 \mathrm{~m}^{3}$.

The differences obtained in the three PVIS are due to the adaptation of the PV irrigation system to the pre-existing irrigation network and the high investment that changing the pipes or other irrigation infrastructures mean. Obviously, changing some of these water infrastructures could improve the system performance but, in most of the cases, are not affordable.

The production of electricity by means of PV systems, in comparison to the conventional local generation, allowed to avoid a remarkable amount of carbon emissions, as also described by other authors. In fact, Masakazu et al. [64] reported an emission rate of 37.1 and $44.5 \mathrm{~g} \mathrm{CO}_{2} \mathrm{e}$ per $\mathrm{kWh}$ for a very large-scale multi-Si PV system simulated respectively in Morocco and France. The environmental impact of four scenarios, considering large size multi-Si PV modules and a yearly irradiance of $1700 \mathrm{kWh} / \mathrm{m}^{2}$, has been studied by Beylot et al. [65] obtaining a range between 37.5 and $53.5 \mathrm{~g} \mathrm{CO}_{2} \mathrm{e}$ 
per $\mathrm{kWh}$. Thus, the energy and environmental performances found in the scientific literature review highlights that the results obtained in this study are comparable with the other international findings.

\subsection{Balance of Energy and Carbon Dioxide Emissions}

The results related to the consumption of fossil fuels are summarized in Table 5. For each PVIS, the total consumptions of electricity or diesel fuel, before and after the installation of the PVIS, was also recorded.

Table 5. Energy intensity and the related emissions of carbon dioxide before and after the installation of the PVIS. The analysis refers to year 2017.

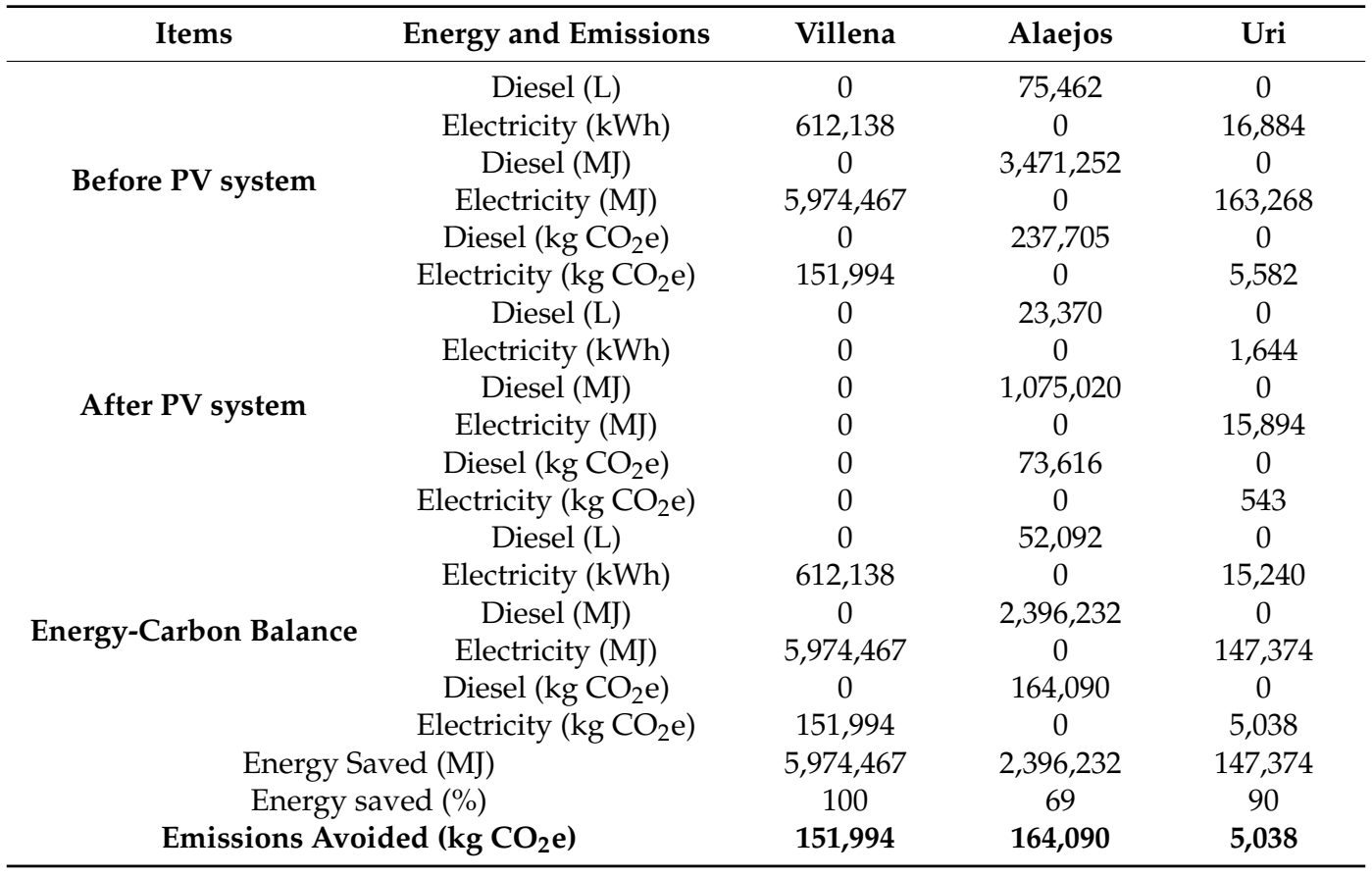

The Villena PVIS produced about $612,000 \mathrm{kWh}$ of electricity, which covered $100 \%$ of the energy required by the irrigation system, also avoiding $100 \%$ of the $\mathrm{CO}_{2}$ emissions. High level of energy savings were fulfilled in the Uri PVIS $(15,240 \mathrm{kWh})$ with about $90 \%$ of energy saved and Alaejos with about $69 \%$ of fuel savings (52,092 L of diesel).

\section{Conclusions}

This study provides evidence of the energy and environmental benefits obtained through the use of stand-alone PVIS. The energy life cycle assessment highlighted the main significant phases that contributed most to the consumptions of primary energy and to the environmental emissions of $\mathrm{CO}_{2} \mathrm{e}$. In fact, emissions into the atmosphere mainly occur using primary energy during the manufacturing process of photovoltaic modules (about $80 \%$ ), while the maintenance of the PV systems was negligible.

The cumulative energy demand assessed in the studied PVIS show the largest yearly incidence for the Italian installation (the smallest one), while the lowest value was found in the Villena site (the largest one).

The energy and carbon payback times represent the time necessary, for the PV irrigation systems, to generate the equal amount of energy and to avoid the same amount of $\mathrm{CO}_{2}$, respectively required and emitted, during the whole life cycle. The EPBT obtained in this study ranged from 1.94 to 5.25 years and the CPBT accounted from 4.62 to 9.38 years. The EROI was also assed for the stand-alone PVIS having values that ranged from 12.9 to 4.8 . These indicators obtained in PVIS underlined the linkage among plant power size and energy and environmental benefits, where large installation achieved better 
performances. This linkage is also supported by the $\mathrm{CO}_{2} \mathrm{e}$ emissions rate of the studied PVIS. In fact, a decreasing trend was observed going from small to large PVIS power size.

The analysis of the energy and environmental performances of the three demonstrators is very satisfactory and comparable to other results obtained worldwide. For example, previous studies based on simulations on large-power PV systems connected to the grid [64,65] report between 37.1 and $53.5 \mathrm{~g}$ $\mathrm{CO}_{2} \mathrm{e}$ per $\mathrm{kWh}$, while we have found in our demonstrators working with a high percentage of PV electricity between 45.9 and $65.6 \mathrm{~g} \mathrm{CO}_{2} \mathrm{e}$. Taking into account that grid-connected systems have better electrical performance because they are not affected by external factor like lack of water or different water needs of the crops along the year, these results are remarkable.

In this study the outcomes of the EPBT, CPBT and EROI are also strongly related to the irrigation needs, which in turn are influenced by other factors as the type of cultivated crops, the weather conditions and the water availability. Improving the operational time of the PV irrigation systems is a critical issue in order to keep EPBT and CPBT as low as possible. In fact, since the PVIS are exclusively devoted to supply energy to the irrigation systems, the production of surplus electricity, to exchange with the grid, cannot occur.

The operational results of the year 2017 are more than positives. In fact, the stand-alone PVIS allowed to save among $69 \%$ and $100 \%$ of the conventional energy previously consumed by the irrigation systems, thus avoiding the emissions of remarkable quantities of carbon emissions.

Finally, this comparison of the results of these three PVIS analyzed in this paper with different sizes (from 40 to $360 \mathrm{kWp}$ ), has shown the relationship between the PVIS size and the environmental performance: the bigger the PV generator size, the better the environmental indexes.

Author Contributions: G.T. conceived and designed the experiments, wrote the manuscript, collected and analyzed the data. L.M. conceived and designed the experiments and revised the manuscript. I.C. and R.H. collect the data. A.P., L.L. and L.N. revised the manuscript. All authors read and approved the final manuscript.

Funding: This work was supported by the European Union's Horizon 2020 research and innovation program under grant agreement No. 640771.

Conflicts of Interest: The authors declare no conflict of interest.

\section{References}

1. Renewable Energy in Europe 2017: Recent Growth and Knock-on Effects-European Environmental Agency. Available online: https:/ / www.eea.europa.eu/publications/renewable-energy-in-europe-2017 (accessed on 18 April 2018).

2. Delfanti, L.; Colantoni, A.; Recanatesi, F.; Bencardino, M.; Sateriano, A.; Zambon, I.; Salvati, L. Solar plants, environmental degradation and local socioeconomic contexts: A case study in a Mediterranean country. Environ. Impact Assess. 2016, 61, 88-93. [CrossRef]

3. Desideri, U.; Proietti, S.; Zepparelli, F.; Sdringola, P.; Bini, S. Life Cycle Assessment of a ground-mounted 1778 kWp photovoltaic plant and comparison with traditional energy production systems. Appl. Energy 2012, 97, 930-943. [CrossRef]

4. Xu, L.; Zhang, S.; Yang, M.; Li, W.; Xu, J. Environmental effects of China's solar photovoltaic industry during 2011-2016: A life cycle assessment approach. J. Clean. Prod. 2018, 170, 310-329. [CrossRef]

5. Ghafoor, A.; Munir, A. Design and economics analysis of an off-grid PV system for house hold electrification. Renew. Sustain. Energy Rev. 2015, 42, 496-502. [CrossRef]

6. Booth, S. Here comes the sun: How securities regulations cast a shadow on the growth of community solar in the United States. UCLA Law Rev. 2014, 61, 760-811.

7. Barelli, L.; Bidini, G.; Bonucci, F.; Castellini, L.; Castellini, S.; Ottaviano, A.; Pelosi, D.; Zuccari, A. Dynamic Analysis of a Hybrid Energy Storage System (H-ESS) Coupled to a Photovoltaic (PV) Plant. Energies 2018, 11, 396. [CrossRef]

8. Cucchiella, F.; D'Adamo, I.; Gastaldi, M. Economic Analysis of a Photovoltaic System: A Resource for Residential Households. Energies 2017, 10, 814. [CrossRef] 
9. 2016 Snapshot of Global Photovoltaic Markets. Available online: http://www.iea-pvps.org/fileadmin/ $\mathrm{dam} / \mathrm{public} / \mathrm{report} /$ statistics/IEA-PVPS_-_A_Snapshot_of_Global_PV_-_1992-2016_1_.pdf (accessed on 2 August 2018).

10. Wong, J.H.; Royapoor, M.; Chan, C.W. Review of life cycle analyses and embodied energy requirements of single-crystalline and multi-crystalline silicon photovoltaic systems. Renew. Sustain. Energy Rev. 2016, 58, 608-618. [CrossRef]

11. Li, T.; Roskilly, A.P.; Wang, Y. Life cycle sustainability assessment of grid-connected photovoltaic power generation: A case study of Northeast England. Appl. Energy 2017. [CrossRef]

12. Beccali, M.; Cellura, M.; Longo, S.; Guarino, F. Solar heating and cooling systems versus conventional systems assisted by photovoltaic: Application of a simplified LCA tool. Sol. Energy Mater. Sol. C 2016, 156, 92-100. [CrossRef]

13. Asdrubali, F.; Baldinelli, G.; D'Alessandro, F.; Scrucca, F. Life cycle assessment of electricity production from renewable energies: Review and results harmonization. Renew. Sustain. Energy Rev. 2015, 42, 1113-1122. [CrossRef]

14. Bayod-Rújula, A.A.; Lorente-Lafuente, A.M.; Cirez-Oto, F. Environmental assessment of grid connected photovoltaic plants with 2-axis tracking versus fixed modules systems. Energy 2011, 36, 3148-3158. [CrossRef]

15. Koppelaara, R.H.E.M. Solar-PV energy payback and net energy: Meta-assessment of study quality, reproducibility, and results harmonization. Renew. Sustain. Energy Rev. 2017, 72, 1241-1255. [CrossRef]

16. Fu, Y.; Liu, X.; Yuan, Z. Life-cycle assessment of multi-crystalline photovoltaic (PV) systems in China. J. Clean. Prod. 2015, 86, 180-190. [CrossRef]

17. Colombo, E.; Rocco, M.V.; Toro, C.; Sciubba, E. An exergy-based approach to the joint economic and environmental impact assessment of possible photovoltaic scenarios: A case study at a regional level in Italy. Ecol. Model. 2015, 318, 64-74. [CrossRef]

18. Yu, M.; Halog, A. Solar Photovoltaic Development in Australia-A Life Cycle Sustainability Assessment Study. Sustainability 2015, 7, 1213-1247. [CrossRef]

19. Yang, D.; Liu, J.; Yang, J.; Ding, N. Life-cycle assessment of China's multi-crystalline silicon photovoltaic modules considering international trade. J. Clean. Prod. 2015, 94, 35-45. [CrossRef]

20. Stylos, N.; Koroneos, C. Carbon footprint of polycrystalline photovoltaic systems. J. Clean. Prod. 2014, 64, 639-645. [CrossRef]

21. Akinyele, D.O.; Rayudu, R.K. Comprehensive techno-economic and environmental impact study of a localised photovoltaic power system (PPS) for off-grid communities. Energy Convers. Manag. 2016, 124, 266-279. [CrossRef]

22. Petrillo, A.; De Felice, F.; Jannelli, E.; Autorino, C.; Minutillo, M.; Lubrano, L.A. Life cycle assessment (LCA) and life cycle cost (LCC) analysis model for a stand-alone hybrid renewable energy system. Renew. Energy 2016, 95, 337-355. [CrossRef]

23. Sharma, R.; Tiwari, G.N. Life cycle assessment of stand-alone photovoltaic (SAPV) system under on-field conditions of New Delhi, India. Energy Policy 2013, 63, 272-282. [CrossRef]

24. Kaldellis, J.K.; Zafirakis, D.; Kondili, E. Energy pay-back period analysis of stand-alone photovoltaic systems. Renew. Energy 2010, 35, 1444-1454. [CrossRef]

25. Chel, A.; Tiwari, G.N. A case study of a typical $2.32 \mathrm{kWP}$ stand-alone photovoltaic (SAPV) in composite climate of New Delhi (India). Appl. Energy 2011, 88, 1415-1426. [CrossRef]

26. Garcıa-Valverde, R.; Miguel, C.; Martınez-Be'jar, R.; Urbina, A. Life cycle assessment study of a $4.2 \mathrm{kWp}$ stand-alone photovoltaic system. Sol. Energy 2009, 83, 1434-1445. [CrossRef]

27. Muhsen, D.H.; Ghazali, A.B.; Khatib, T.; Abdulabbas, T.E. Techno-economic study and optimal sizing of a stand-alone photovoltaic water pumping system. Int. Trans. Electr. Energy Syst. 2017, 27, e2355. [CrossRef]

28. Valer, L.R.; Melendez, T.A.; Fedrizzi, M.C.; Zilles, R.; de Moraes, A.M. Variable-speed drives in photovoltaic pumping systems for irrigation in Brazil. Sustain. Energy Technol. Assess. 2016, 15, 20-26. [CrossRef]

29. Petroselli, A.; Biondi, P.; Colantoni, A.; Monarca, D.; Cecchini, M.; Marucci, A.; Cividino, S. Photovoltaic Pumps: Technical and Practical Aspects for Applications in Agriculture. Math. Probl. Eng. 2012, 2012, 343080. [CrossRef]

30. Fernandez, J.; Narvarte, L.; Poza, F. Improvement of photovoltaic pumping systems based on standard frequency converters by means of programmable logic controllers. Sol. Energy 2010, 84, 101-109. [CrossRef] 
31. Zhang, W.; He, X.; Zhang, Z.; Gong, S.; Zhang, Q.; Zhang, W.; Liu, D.; Zou, C.; Chen, X. Carbon footprint assessment for irrigated and rainfed maize (Zea mays L.) production on the Loess Plateau of China. Biosyst. Eng. 2018, 167, 75-86. [CrossRef]

32. Tahmasebi, M.; Feike, T.; Soltani, A.; Ramroudi, M.; Ha, N. Trade-off between productivity and environmental sustainability in irrigated vs. rainfed wheat production in Iran. J. Clean. Prod. 2018, 174, 367-379. [CrossRef]

33. Grant, T.; Beer, T. Life cycle assessment of greenhouse gas emissions from irrigated maize and their significance in the value chain. Anim. Prod. Sci. 2008, 48, 375-381. [CrossRef]

34. Ali, B. Comparative assessment of the feasibility for solar irrigation pumps in Sudan. Renew. Sustain. Energy Rev. 2018, 81, 413-420. [CrossRef]

35. Wettstein, S.; Muir, K.; Scharfy, D.; Stucki, M. The Environmental Mitigation Potential of Photovoltaic-Powered Irrigation in the Production of South African Maize. Sustainability 2017, 9, 1172. [CrossRef]

36. Cherif, H.; Champenois, G.; Belhadj, J. Environmental life cycle analysis of a water pumping and desalination process powered by intermittent renewable energy sources. Renew. Sustain. Energy Rev. 2016, 59, 1504-1513. [CrossRef]

37. Yang, J.; Olsson, A.; Yan, J.; Chen, B.A. Hybrid Life-Cycle Assessment of $\mathrm{CO}_{2}$ Emissions of a PV Water Pumping System in China. Energy Procedia 2014, 61, 2871-2875. [CrossRef]

38. High Power Photovoltaic Irrigation Systems. Available online: http:/ / maslowaten.eu/?page_id=579\&lang=en (accessed on 15 February 2018).

39. Environmental Management-Life Cycle Assessment-Principles and Framework. International Standard Organization. Available online: https:// web.stanford.edu/class/cee214/Readings/ISOLCA.pdf (accessed on 15 February 2018).

40. Environmental Management—Life Cycle Assessment—Requirements and Guidelines. European Standard. Available online: https:/ / www.iso.org/obp/ui/\#iso:std:iso:14044:ed-1:v1:en (accessed on 23 July 2018).

41. ISO 14064-1, 2012. Greenhouse Gases-Part 1: Specification with Guidance at the Organization Level for Quantification and Reporting of Greenhouse Gas Emissions and Removals. European Standard. Available online: https://www.iso.org/obp/ui/\#iso:std:iso:14064:-1:ed-1:v1:en (accessed on 23 July 2018).

42. Greenhouse Gases-Carbon Footprint of Products-Requirements and Guidelines for Quantification and Communication. European Standard. Available online: https://www.iso.org/obp/ui/\#iso:std:iso:ts:14067: ed-1:v1:en (accessed on 23 July 2018).

43. Kommalapati, R.; Kadiyala, A.; Shahriar, M.T.; Huque, Z. Review of the Life Cycle Greenhouse Gas Emissions from Different Photovoltaic and Concentrating Solar Power Electricity Generation Systems. Energies 2017, 10, 350. [CrossRef]

44. Vellini, M.; Gambini, M.; Prattella, V. Environmental impacts of PV technology throughout the life cycle: Importance of the end-of-life management for Si-panels and CdTepanels. Energy 2017, 138, 1099-1111. [CrossRef]

45. Huang, B.; Zhao, J.; Chai, J.; Xue, B.; Zhao, F.; Wang, X. Environmental influence assessment of China's multi-crystalline silicon (multi-Si) photovoltaic modules considering recycling process. Sol. Energy 2017, 143, 132-141. [CrossRef]

46. Gerbinet, S.; Belboom, S.; Léonard, A. Life Cycle Analysis (LCA) of photovoltaic panels: A review. Renew. Sustain. Energy Rev. 2014, 38, 747-753. [CrossRef]

47. Latunussa, C.E.L.; Ardente, F.; Blengini, G.A.; Mancini, L. Life Cycle Assessment of an innovative recycling process for crystalline silicon photovoltaic panels. Sol. Energy Mater. Sol. C 2016, 156, 101-111. [CrossRef]

48. Directive 2012/19/EU. European Parliament and of the Council. Waste Electrical and Electronic Equipment (WEEE) Text with EEA Relevance. Available online: https:/ / eur-lex.europa.eu/legal-content/EN/TXT/ ?uri=CELEX:32012L0019 (accessed on 13 January 2018).

49. Bogacka, M.; Pikon, K.; Landrat, M. Environmental impact of PV cell waste scenario. Waste Manag. 2017, 70, $198-203$. [CrossRef] [PubMed]

50. IPCC. Climate Change 2014: Synthesis Report. Contribution of Working Groups I, II and III to the Fifth Assessment Report of the Intergovernmental Panel on Climate Change; Pachauri, R.K., Meyer, L.A., Eds.; IPCC: Geneva, Switzerland, 2014; p. 151.

51. Wernet, G.; Bauer, C.; Steubing, B.; Reinhard, J.; Moreno-Ruiz, E.; Weidema, B. The ecoinvent database version 3 (part I): Overview and methodology. Int. J. Life Cycle Assess. 2016, 21, 1218-1230. [CrossRef]

52. Nassiri, S.M.; Singh, S. Study on energy use efficiency for paddy crop using data envelopment analysis (DEA) technique. Appl. Energy 2009, 86, 1320-1325. [CrossRef] 
53. Rotz, C.A.; Montes, F.; Chianese, D.S. The carbon footprint of dairy production systems through partial life cycle assessment. J. Dairy Sci. 2010, 93, 1266-1282. [CrossRef] [PubMed]

54. Life Cycle Inventories of Electricity Mixes and Grid. Version 1.3. Available online: http:/ /studylib.net/doc/ 18476974/life-cycle-inventories-of-electricity-mixes-and-grid---esu (accessed on 15 December 2017).

55. Fattori di Emissione Atmosferica di $\mathrm{CO}_{2} \mathrm{e}$ Altri Gas a Effetto Serra del Settore Elettrico. Available online: http: //www.isprambiente.gov.it/files2017/pubblicazioni/rapporto/R_257_17.pdf (accessed on 20 October 2017).

56. International Energy Agency. $\mathrm{CO}_{2}$ Emissions from Fuel Combustion. Statistics...\# IPCC 2006. Revised IPCC Guidelines for National Greenhouse Gas Inventories: Reference Manual. Available online: http:/ /www.iea.org/ stats/index.asp (accessed on 10 January 2018).

57. Luo, W.; Khoo, Y.S.; Kumara, A.; Low, J.S.C.; Lia, Y.; Tan, Y.S.; Wang, Y.; Aberle, A.G.; Ramakrishna, S. A comparative life-cycle assessment of photovoltaic electricity generation in Singapore by multicrystalline silicon technologies. Sol. Energy Mater. Sol. C 2018, 174, 157-162. [CrossRef]

58. Chen, W.; Hong, J.; Yuan, X.; Liu, J. Environmental impact assessment of monocrystalline silicon solar photovoltaic cell production: A case study in China. J. Clean. Prod. 2016, 112, 1025-1032. [CrossRef]

59. Hou, G.; Sun, H.; Jiang, Z.; Pan, Z.; Wang, Y.; Zhang, X.; Zhao, Y.; Yao, Q. Life cycle assessment of grid-connected photovoltaic power generation from crystalline silicon solar modules in China. Appl. Energy 2016, 164, 882-890. [CrossRef]

60. Leccisi, E.; Raugei, M.; Fthenakis, F. The Energy and Environmental Performance of Ground-Mounted Photovoltaic Systems-A Timely Update. Energies 2016, 9, 622. [CrossRef]

61. Mann, S.A.; de Wild-Scholten, M.J.; Fthenakis, V.; van Sark, W.G.J.H.M.; Sinke, W.C. The energy payback time of advanced crystalline silicon PV modules in 2020: A prospective study. Prog. Photovolt. Res. Appl. 2014, 22, 1180-1194. [CrossRef]

62. Bhandari, K.P.; Collier, J.M.; Ellingson, R.J.; Apul, D.S. Energy payback time (EPBT) and energy return on energy invested (EROI) of solar photovoltaic systems: A systematic review and meta-analysis. Renew. Sustain. Energy Rev. 2015, 47, 133-141. [CrossRef]

63. Hall, C.A.S.; Balogh, S.; Murphy, D.J.R. What is the Minimum EROI that a Sustainable Society Society Must Have? Energies 2009, 2, 25-47. [CrossRef]

64. Masakazu, I.; Lespinats, S.; Merten, J.; Malbranche, P.; Kurokawa, K. Life cycle assessment and cost analysis of very largescale PV systems and suitable locations in the world. Prog. Photovolt. Res. Appl. 2016, 24, 159-174.

65. Beylot, A.; Payet, J.; Puech, C.; Adra, N.; Jacquin, P.; Blanc, I.; Beloin-Saint-Pierre, D. Environmental impacts of large-scale grid-connected ground-mounted PV installations. Renew. Energy 2014, 61, 2-6. [CrossRef] 